\title{
Innovation in Enhanced Oil Recovery
}

\author{
Omar Chaalal* \\ Department of Chemical Engineering, Abu Dhabi University, Unites Arab Emirates
}

Submission: May 07, 2018; Published: May 14, 2018

*Corresponding author: Omar Chaalal, Department of Chemical Engineering, Abu Dhabi University, Abu Dhabi, Unites Arab Emirates, Email: omar.chaalal@adu.ac.ae

\begin{abstract}
Fulfilling worldwide energy demand in the $21^{\text {st }}$ century is the most challenging problem. New kinds of energy sources along with the new technological breakthroughs to maintain enough oil and gas supply are needed to meet the tremendous rise in world's energy demand. Recent dramatic fall in oil prices has accentuated the problem. Now, the challenge is to fill out the increasing gap between energy demand and supply with more cost effective techniques. Recently, Abu Dhabi University has filed a patent application (US-Patent Application No 15/342,664) reporting the invention of Dr. Omar Chaalal that fulfills practically all criteria discussed above. In this paper, a 'green' alternative to chemical flooding is proposed. The new technology proposed uses two types of plant extracts that increases the total oil recovery to $96 \%$ of initial oil in place (IOIP) during the tertiary recovery mode. While water flood recovered around $50 \%$ of the IOIP, $0.5 \%$ wt of the natural plant extract recovered $77 \%$ in the secondary recovery mode. The additives were extracted from two plants available in the United Arab Emirates (Product A and Product B). These natural extracts proved to be very effective in formations containing water with a salinity range of 70,000 to $180,000 \mathrm{ppm}$ with temperature going up to $100^{\circ} \mathrm{C}$.
\end{abstract}

Keywords: EOR; Green flooding; High salinity; High temperature; Reservoir; IFT

\section{Introduction}

Oil recovery refers to the process by which crude oil is extracted from beneath the Earth's surface. Oil recovery can be divided into three phases: Primary, Secondary and Tertiary. The primary phase production uses the reservoir's natural energy (fluid and rock expansion, solution-gas drive, gravity drainage, and aquifer influx) to produce oil. This phase allows about $5 \%$ to $10 \%$ of the oil in the reservoir to be extracted [1-5].

In the secondary phase production, also named as "secondary recovery", water-flooding process uses water injection to increase the production from the oil reservoir. Secondary recovery allows additional $25 \%$ to $30 \%$ of the extracted oil from the reservoir. However, even after a long term water-flooding process, some amounts of oil still remain trapped in the reservoir due to a high capillary pressure [6-10].

The aim of the tertiary phase recovery of oil is to recover crude oil remained after the primary and secondary oil recovery. In this phase different materials are injected together with water to improve the flow between oil, gas and rock. In this phase, additional $20 \%$ to $30 \%$ of the oil in the reservoir can be extracted. Figure 1 gives a general idea how the oil is extracted in the tertiary phase [11-15].

It is known that the interfacial tension (IFT) between crude oil and water should be significantly very low for a successful enhanced oil recovery. This can be achieved using surfactant flooding. Generally, the main requirement of surfactant processes is targeting of ultralow interfacial tensions. For this purpose, the right surfactant should be selected and evaluated at low and economic concentrations. On the other hand, maintaining low interfacial tension during the displacement process is a critical challenge because of dilution and adsorption effects in the reservoir [15-20].

The presently known technologies suggest the use of various materials and processes such as $\mathrm{CO} 2$ injection, surfactant agent injection, natural gas miscible injection, and steam recovery, in particular, during the tertiary oil recovery phase. In this phase the injection of different materials improve the flow between oil, gas and rock, and to recover crude oil still remained after the primary and secondary oil recovery phases. Oil that is left behind after water flooding is still present because either it has not been contacted by the injected fluid, or because of the presence of the capillary forces that exist between oil, water and the porous rock in the contacted portions which trap and retain said oil [21-25].

It is known in the state of the art the use of surfactant agents that are introduced into the reservoir to increase oil recovery by lowering the interfacial tension between oil and water. Trapped oil droplets are mobilized due to a reduction in interfacial tension between oil and water. The coalescence of these drops leads to a local increase in oil saturation. An oil bank starts to flow, mobilizing any residual oil in front. Eventually, the ultimate residual oil is determined by interfacial tension between oil and surfactant solution behind the oil collection [26]. 
Nowadays, methods for improving oil recovery, in particular those concerned with lowering the interstitial oil saturation, have received a great interest in the industry. There are many different types of chemical compositions used in the oil recovery process involving the individual or combined injection of surfactants that lower the surface interfacial tension between the injected water and crude oil in the reservoir and or change the wet ability of the reservoir rock surface, allowing the desorption of crude oil. During the past several decades, various methods have been sought in order to efficiently increase the secondary and tertiary oil recovery process, while improving the economic viability and efficiency of operations. Examples of said method includes, but are not limited to, chemicals, polymer, surfactant and alkaline flooding techniques. Although said methods have showed to be responsible in decreasing the interfacial tension while increasing the sweep efficiency, there is still a need of enhanced oil recovery from the reservoirs, in particular where such oil recovery process should be carried out from high salinity and high temperature of oil reservoirs. Most of the available surfactants used in oil recovery operations are either ineffective at high level of salinity hardness of the water, or incapable to stand the higher temperatures of many processes.

Therefore there is a need to provide a method for an efficient secondary and tertiary water flooding of heterogeneous oil reservoirs at high salinity and high temperature. In particular there is a need to provide a novel composition able to improve oil recovery from reservoirs by efficiently reducing interfacial tension while increasing the volumetric sweep efficiency of fractured and or heterogeneous oil reservoirs.

In this paper a green product that is environmental friendly, non-toxic, easy and safe to handle is presented. The new product showed an oil recovery of $96.5 \%$ at reservoir temperature. This recovery is a breakthrough in the field of enhanced oil recovery.

Many oil formations contain water having high salinity and or high concentrations of divalent ions such as calcium or magnesium dissolved therein, and are additionally at temperature high temperatures. Most of the available surfactants used in oil recovery operations are either ineffective in high salinity or high hardness waters, or incapable to stand the higher temperatures encountered in many formations. A powerful natural product that improves enhance oil reservoirs recovery through the reduction of interfacial tension and increases the volumetric sweep efficiency of fractured and or heterogeneous oil reservoirs is introduced in this innovation. The novel green surfactant for EOR is extracted from two plants available in the United Arab Emirates (Product A and Product B). This natural agent proves to be very effective in formations containing water whose salinity is from 70,000 to 180,000 parts per million total dissolved solids and also having temperatures as high as $100{ }^{\circ} \mathrm{C}$. The agent is mixed with the formation water and is stable over a wide range of formation temperatures and water salinity. Figure 1 shows how this green water is injected in the reservoir.

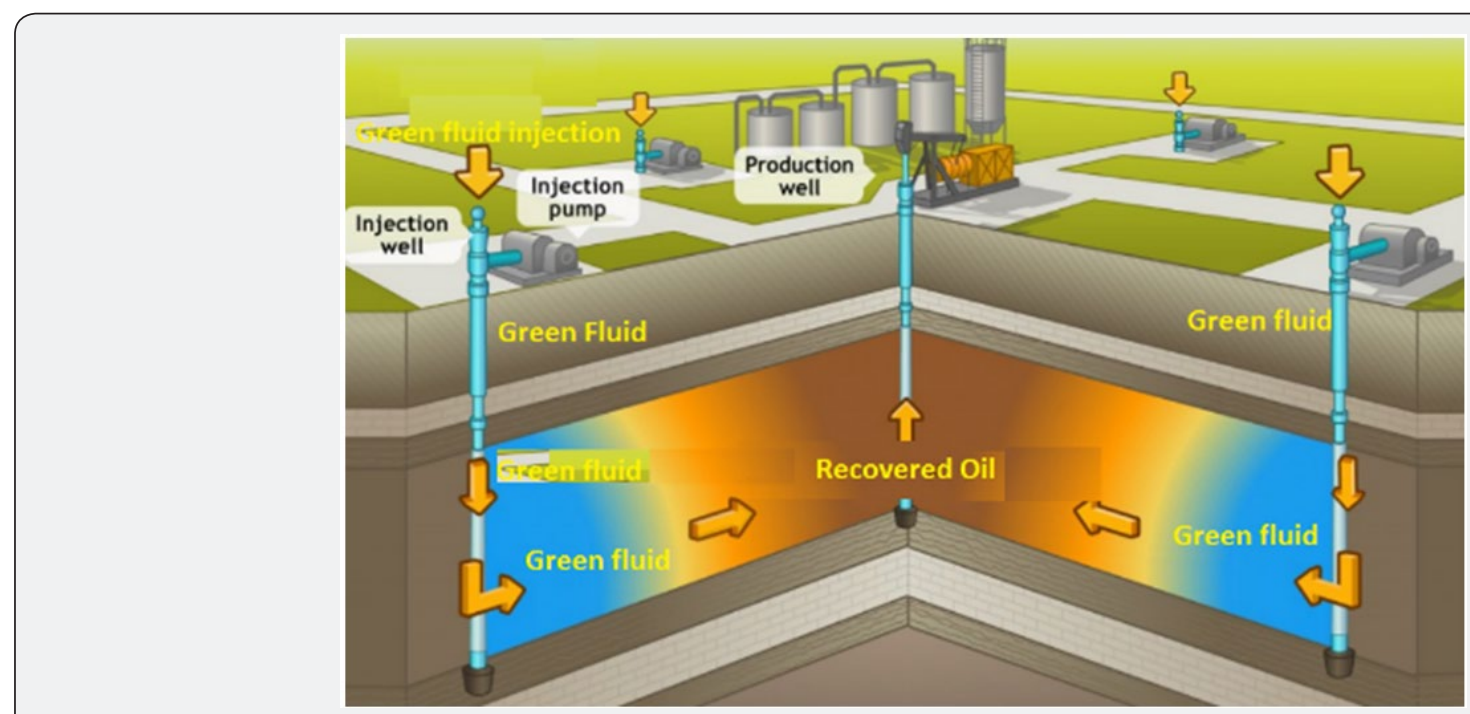

Figure 1: Schematic drawing of the injection of green water in the reservoir.

Conventional chemical flooding schemes that use chemical surfactants in order to reduce oil-water interfacial tension are ineffective, expensive, and hostile to the environment. Many oilbearing formations have high salinity and or high concentrations of divalent ions such as calcium or magnesium dissolved. Under such an environment as well as under high temperature conditions, conventional surfactants break down, becoming ineffective. In addition, fractures and natural heterogeneity offer additional complexity to the process. A series of core-flood tests were conducted using real cores from the Abu Hassa oil field of Abu Dhabi. The high recovery cannot be explained through interfacial tension (IFT) reduction alone, even though IFT was reduced 10 fold for a concentration of $0.5 \%$ wt of injection fluid. Similarly, polymeric action cannot explain the sweep efficiency as the viscosity of the injected fluid was only slightly higher than water. It is the same for any impact on wettability that in itself wouldn't be able to increase tertiary recovery to that extent. It is explained that there are natural components, such 


\section{Recent Advances in Petrochemical Science}

as lipid, fructose, Sucrose, Maltose, plant protein, etc. that have a synergistic role to play in order to increase the efficiency of the recovery process. It turns out that the overall impact of the injecting fluid is positive effect on IFT, total volumetric efficiency, wettability, and others that are not readily observable with synthetic materials, but are available for natural products. It is expected that the newly invented process will be particularly useful in presence of fractures and or complex reservoir heterogeneities that usually impede displacement efficiency. A future research proposal is under preparation in order to understand the mechanisms involved with the recovery process.

\section{References}

1. Geiger P (2006) CO2 EOR and Sequestration in Wyoming", Anadarko Petroleum, $4^{\text {th }}$ Annual EOR Carbon Management Workshop, The Woodlands Waterway Marriott Hotel and Conference Center. Houston, Texas, USA, pp. 4-5.

2. Thomas S, Farouq ASM (1999) Status and Assessment of Chemical Oil Recovery Methods. Energy Sources 21(1-2): 177-189.

3. Thomas S, Farouq ASM (1993) Proceeding of the $21^{\text {st }}$ Australian Chemical Engineering Conference (Chemeca 93), Melbourne, Australia.

4. Chang HL (1978) Polymer Flooding Technology Yesterday, Today, and Tomorro. J Petrol Technol 30(8): 1113-1128.

5. Somasundaran P, Hanna HS (1979) Adsorption of Sulfonates on Reservoir Rocks. Soc Petrol Eng J 19(4): 221-232.

6. YadaliJamaloei B (2009) Insight into the Chemistry of SurfactantBased Enhanced Oil Recovery. Recent Patents on Chemical Engineering 2(1): 1-10.

7. Krumrine PH, Falcone JS (1983) Proceeding of the SPE International Symposium on Oilfield and Geothermal Chemistry, Denver, CO.

8. Mayer EH, Berg RL, Carmichael JD, Weinbrandt RM (1983) Innovation in Oil: A sustainable EOR technique for high salinity and high temperature formations. J Petrol Technol, pp. 209-221.

9. Johnson CE (1976) J Petrol Technol 1: 85-91.

10. Reed RL, Healy RN (1977) Improved Oil Recovery by Surfactant and Polymer Flooding. In: Shah DO, Schechter RS (Eds.), Academic Press, New York, USA.

11. Dreher KD, Gogarty WB, Rheol J ( 1979) 23: 209-229.
12. Gogarty WB, Tosch WC (1968) J Petrol Technol 20: 1407-1412.

13. Thomas S, Farouq ASM (1986) Proceedings of the $37^{\text {th }}$ Annual Technical Meeting of the Petroleum Society of CIM. Calgary, Alberta, Canada.

14. Earlougher RC, O'Neal JE, Surkalo H (1975) Proceedings of the Rocky Mountain Regional Meeting of the Society of Petroleum Engineers, Denver, CO, USA.

15. Wyatt K, Pitts MJ, Surkalo H (2002) Proceedings of the SPE Eastern Regional Meeting, Lexington, Kentucky, USA.

16. Gao ST, Li HB, Yang ZY, Pitts MJ, Surkalo H, et al. (1996) SPE Reservoir Engineer. pp. 181-188.

17. Hitzman DO, Sperl GT (1994) Proceedings of the SPE/DOE ninth Symposium on Improved Oil Recovery. Tulsa, OK, USA. P. 105.

18. Zakri AY, Almehaideb R, Chaalal O (2001) Enhanced Oil Recovery from UAE Limestone Reservoirs Using Bacteria Flooding an Experimental Approach Japanese. Petroleum Institute Journal 44(5): 267-276.

19. Bryant RS (1994) Chem Eng Res Des 72 : 144-151.

20. Bernard FP, Connan J, Magot M (1992) Proceedings of the SPE Annual Technical Conference and Exhibition. Washington, DC, USA. 24811: 467-476.

21. Ridding RE, Awramik SM (2000) Microbial Sediments. In: Ridding RE, Awramik SM (Eds.), Springer Verlag Berlin and Heidelberg GmbH \& Co KG, illustrated edition, p. 118.

22. Sydansk RD, Romero-Zerón L (2011) Reservoir Conformance Improvement. Richardson, Texas: Society of Petroleum Engineers, USA.

23. Enick R, Olsen D (2012) Mobility and Conformance Control for Carbon Dioxide Enhanced Oil Recovery (CO2-EOR) via Thickeners, Foams, and Gels-A Detailed Literature Review of 40 Years of Research and Pilot Tests. SPE journal, USA.

24. Hirasaki GJ, Miller CA, Puerto M (2011) Recent Advances in Surfactant EOR. SPE Journal 16(4): 889-907.

25. Allen DK, Tao BY (2002) Synthesis and characterization of maltose fatty acid monoesters as Biosurfactants. Journal of Surfactants and Detergents 5(3): 245-255.

26. Wardhono EY, Zafimahova-Ratisbonne A, Jean-Louis L, Khashayar S, Daniele C, et al. (2014) Optimization of the formulation of water in oil emulsions entrapping polysaccharide by increasing the amount of water and the stability. Canadian Journal of Chemical Engineering 92(7): 1189-1196.

\section{Your next submission with Juniper Publishers} will reach you the below assets

- Quality Editorial service

- Swift Peer Review

- Reprints availability

- E-prints Service

- Manuscript Podcast for convenient understanding

- Global attainment for your research

- Manuscript accessibility in different formats

( Pdf, E-pub, Full Text, Audio)

- Unceasing customer service

Track the below URL for one-step submission https://juniperpublishers.com/online-submission.php 